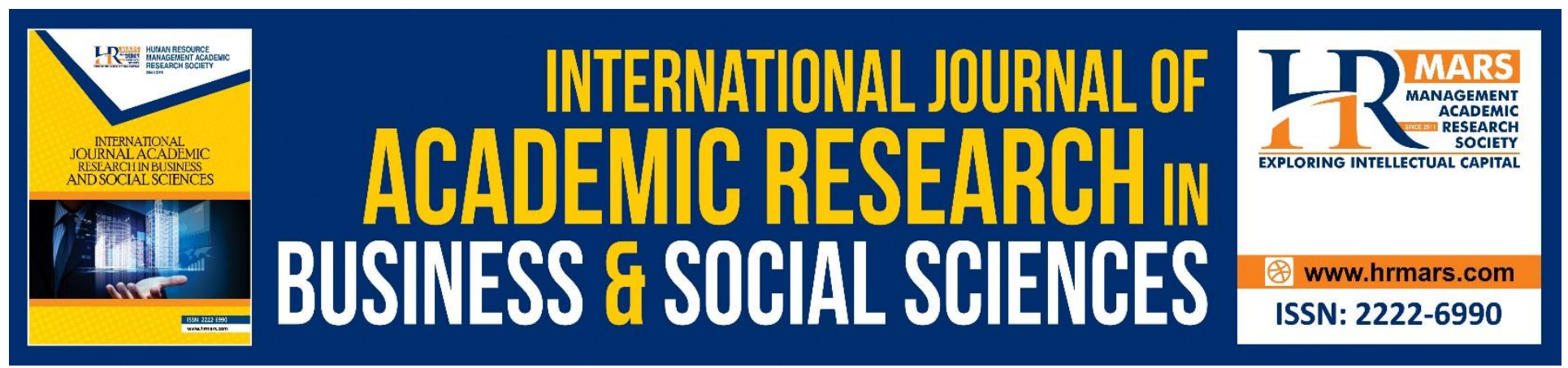

\title{
Investigation of Factors Influencing Customer Loyalty in Malaysia and Jordan Hotel Industry
}

Ghaith Abdulraheem Ali Alsheikh, Mutia Sobihah binti abd Halim, Ahmad Y.A. Ayassrah, Abdul Malek bin Tambi, Enas Ali Theeb Alnawafleh

To Link this Article: http://dx.doi.org/10.6007/IJARBSS/v8-i12/5074 DOI: $10.6007 /$ IJARBSS/v8-i12/5074

Received: 23 Nov 2018, Revised: 19 Dec 2018, Accepted: 24 Dec 2018

Published Online: 29 Dec 2018

In-Text Citation: (Alsheikh, Halim, Ayassrah, Tambi, \& Alnawafleh, 2018)

To Cite this Article: Alsheikh, G. A. A., Halim, M. S. binti abd, Ayassrah, A. Y. A., Tambi, A. M. bin, \& Alnawafleh, E. A. T. (2018). Investigation of Factors Influencing Customer Loyalty in Malaysia and Jordan Hotel Industry. International Journal of Academic Research in Business and Social Sciences, 8(12), 797-809.

Copyright: (C) 2018 The Author(s)

Published by Human Resource Management Academic Research Society (www.hrmars.com)

This article is published under the Creative Commons Attribution (CC BY 4.0) license. Anyone may reproduce, distribute, translate and create derivative works of this article (for both commercial and non-commercial purposes), subject to full attribution to the original publication and authors. The full terms of this license may be seen

at: http://creativecommons.org/licences/by/4.0/legalcode

Vol. 8, No. 12, 2018, Pg. 797 - 809

http://hrmars.com/index.php/pages/detail/IJARBSS

JOURNAL HOMEPAGE

Full Terms \& Conditions of access and use can be found at http://hrmars.com/index.php/pages/detail/publication-ethics 


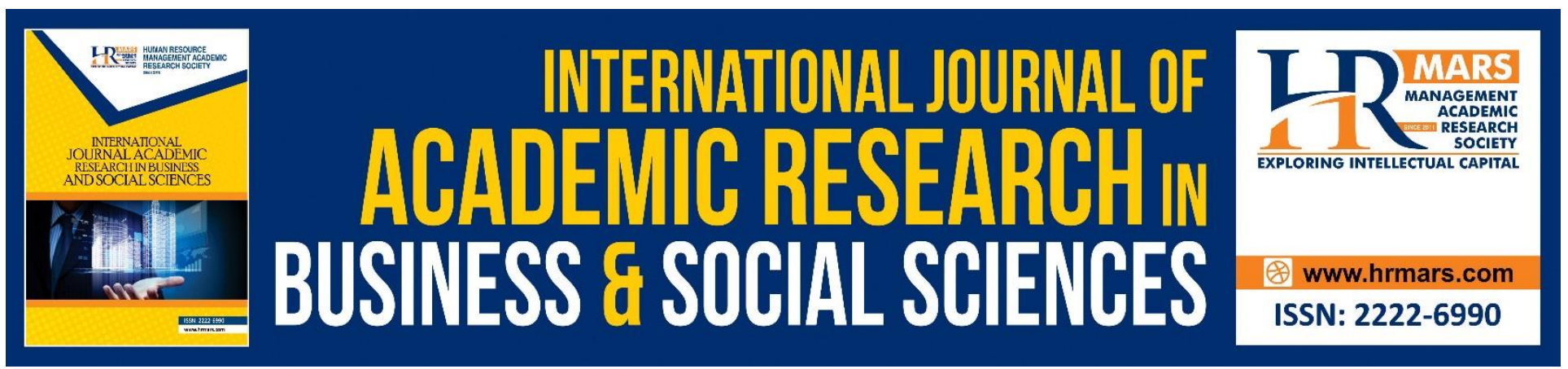

\title{
Investigation of Factors Influencing Customer Loyalty in Malaysia and Jordan Hotel Industry
}

Ghaith Abdulraheem Ali Alsheikh (1), Mutia Sobihah binti abd halim ${ }^{(1) *}$, Ahmad Y.A. Ayassrah ${ }^{(2)}$, Abdul Malek bin Tambi (3), Enas Ali Theeb Alnawafleh (4)

Universiti Sultan Zainal Abidin (UniSZA)/Faculty of Economics \& Management Sciences $(1,3)$ Irbid National University ${ }^{(2)}$

Al-Balqa`Applied University / Ma'an College (4)

Email: Aligaith89@yahoo.com ${ }^{(1)}$, Ahmadayassrah_78@yahoo.com ${ }^{(2)}$, Malekahmad@unisza.edu.my ${ }^{(3)}$,Enas.nawafleh@bau.edu.jo ${ }^{(4)}$

\begin{abstract}
This study aims to proffer solutions to customer loyalty challenges at these destinations by proposing and validating customer loyalty model using relationship marketing and social exchange theory. Based on the underpinning theories, this study analyzed the direct and indirect influence of brand image, trust, convenience and emotion on customer loyalty of five star hotels in Malaysia and Jordan. Further, the mediating effect of customer satisfaction on the relationship between exogenous latent variables and endogenous latent variable was investigated. A total of 384 and 371customers respectively of three famous hotels under the management of Starwood were sampled using convenience sampling method for data analysis from Malaysia and Jordan. SPSS version 21.0 software was used for the analysis. However, the empirical results showed partial mediation effects on the relationship between brand image, trust, convenience, emotion and customer loyalty in respect of Malaysian hotel customers. In Jordan hotels, satisfaction does not mediate the relationship between trust and customer loyalty but partially mediate between emotion, brand image, convenience and customer loyalty. In summary, the findings of this study will narrow the perception of the top echelon of these hotels on the actual factors to focus in order to earn loyalty of their valued customers. This study also contributed to frontier of knowledge by integrating the variables of relationship marketing from the perspectives of two developing countries.
\end{abstract}

Keywords: Customer Loyalty, Customer Satisfaction, Brand Image, Trust, Convenience, Emotion

\footnotetext{
* Corresponding Author: Mutia Sobihah Binti Abd Halim, Faculty of Economics \& Management Sciences, Universiti Sultan Zainal Abidin, 21300 Terengganu, Malaysia. E-mail: mutiasobihah@unisza.edu.my.
} 


\section{INTRODUCTION}

According to prior studies on tourism, governments all over the globe generally support and promote tourism owing to its positive effect on the development and growth of the economy (Cardenaas-Garcia, Sanchez-Rivero \& Pulido-Fernandez, 2015; Mazghouni \& Goaied, 2015; Page, 2014). Specifically, tourism opens avenues for employment opportunities and income and it results in positive balance of payments, boosts tourism supply sector and facilitates overall economic activity growth within the country (Khanna, Papadavid, Tyson \& te Velde, 2016). This led Joppe and Li (2014) to propose the impact of tourism on economic quantitative measurement employed in the development of the economy. Consequently, a distinct literature has developed to measure the effect of tourism on the basis of GDP in order to gauge its contribution to the growth of the economy (Aslan, 2014).

This study is based on the customer loyalty of five star-hotels in both Malaysia and Jordan, there are some common assumptions of internal factors or homogeneity between these two countries, such as they are Muslim countries, developing and low-income countries, and the geographic density of population distribution are influential factors which affect the development of the public and private sectors. There are abundant elements that encourage tourism, including the construction of five-star hotels in these areas. Researchers such as Godolia and Spaho (2014), recommended that as many differences exist between these countries and developed ones, conducting research in such developing economies is an important contribution to the body of knowledge.

In relation to the above, loyal customer can also be viewed as a source to maximize revenues among organizations, which in turn, could lead to predictable sales and return (Chen, Sch, Kazman \& Matthes, 2016; Karajaluoto, Jayawardhena, Pihlstrom, \& Leppaniemei, 2015). Also, customers that are satisfied and loyal create free advertisement in the form of positive word of mouth (Dogdubay \& Avcikurt, 2009; Shoemaker \& Lewis, 1999). In view of the firm's profitability, a 5\% customer's retention will approximately lead to 25-95\% company profitability (Reicheld, 1996; Yao, 2013). Therefore, the creation of loyal customers is crucial to the generation of profits in firms, and this may be possible through customer satisfaction.

The extensive expansion of hotel services has brought about competitive advantage among service providers. This is compounded by the tourism increase around the globe that necessitated the boost of hotel construction, particularly luxury hotels (five-star hotels). It is thus not surprising that currently, hotels among different categories are in fierce competition to retain customers through customer support services and price-cutting strategies. However, the latter could lead to serious risk of adverse outcomes in terms of long-term profitability of hotels (Kawachart, 2013). More importantly, the critically affected hotels is the luxury class hotels, where the occupancy rate and room rate has been showing a decrease owing to price instability (Kawachart, 2013).

Specifically, Malaysia is increasingly turning into a high-income nation, where people are becoming sensitive with the service quality regardless of costs. In hotels, patrons expectations have increased in regards to timely and reliable customer services and those who are dissatisfied do not hesitate to look for better alternatives (Abdullah \& Hamdan, 2012).

Generally, tourism is influenced by circumstances (regional or international). In Jordan, a sharp decrease in the profitability of tourism industry has been noted in the past five years and this 
has affected the national economy of the country. The top challenges noted in this sector include the unstable political situation in the Middle Eastern region that resulted in the decline of the number of tourists. This is compounded by the negative image that the media has developed about the country concerning instability as opposed to actual reality (stability, security and safety) and as such, it has become important to disseminate the right image (Alrai, 2015).

\section{LITERATURE REVIEW}

A look at the proposed models in literature shows that the relationship quality and customer loyalty are the top variables (Adoyo et al., 2012; Berezina, Cobanoglu, Miller \& Kwansa, 2012; Li, Ye \& Law, 2013). In the present study, relationship development covers image, trust and convenience, and it is mediated by satisfaction - this provides the optimum analysis of the relationship strength (Chu et al., 2016; Magnini, Crotts \& Zehrer, 2011; Shammout, 2007), with the ultimate aim being the realization of customer loyalty (Adoyo et al., 2012).

However, according to Suhartanto (2011), when the empirical analysis is limited to the constructs viewed as determinants of loyalty, the whole empirical gap cannot be revealed and therefore, variables have to be investigated for being relationship quality antecedents along with emotion in terms of social status of hotel rating (Ali, Kim, Li \& Jeon, 2016; Amiri \& Esmailpour, 2014; Nwokorie, 2016; Wilks \& Hemsworth, 2012). Therefore, in the present study the perception of variables (image, trust, convenience, satisfaction) along with emotion will be examined in relation to loyalty and in relation to their contribution in service marketing theories.

As mentioned, one of the present study's proposed independent variables is brand image, and it is described as the mental impression the hotel customer holds either from different channels - advertisements, public relations, word-of-mouth, personal experience in prior consumption, among others (Wu \& Liang, 2009). It is a crucial factor that affects the perceptions of customer evaluations of satisfaction with the service, especially when services are complicated to evaluate (Elbakoush, 2015; Yan, 2015). Several authors stated that image has a role in the cumulative customer satisfaction effect (Shammout, 2007; Suhartanto, 2011; Wu \& Liang, 2009), while others found brand image to be a crucial factor for hotel guests in their recommendation and intention to purchase (Hoq, Sultana \& Amin, 2010). indicating that examining the variable together with other variables will contribute to literature and to academics alike (Wu \& Liang, 2009). In fact, prior studies have recommended the examination of brand image in relation to customer loyalty (Abashah, 2015; Pelegrin-Borondo, AriasOliva \& Olarte-Pascual, 2016; Tasci, 2016; Ullah, Raza \& Chander, 2016).

The next independent variable proposed in this study is trust, referring to the level of confidence developed on the service provider that can contribute to repurchase behavior (Elbakoush, 2015; Warsame, 2015). Trust is a crucial construct in the development of a relationship as evidenced by several studies in literature (Noorashikin \& Ani, 2014; Elbakoush, 2015; Morgan \& Hung, 1994; Warsame, 2015). This belief is supported by Morgan and Hung (1994) who stated that relationship thrives if there is trust between the two parties. This supports the proposal in this study of trust as an independent variable that leads to 5-star hotel customer loyalty in Jordan and Malaysia. It can therefore be stated that the investigation of trust effects on customer loyalty will contribute to the body of knowledge (Ali et al., 2016; Amiri \& Esmailpour, 2014; Liu, Deng, Hu \& Chen, 2015; Razak, Palilati, Hajar \& Madjid, 2016; Suhartanto, 2011). 
The next proposed independent variable in this study is convenience. In this regard, owing to the extensive proliferation of hotel services, it is only logical that guests also take convenience into consideration when deciding their lodging (Noorashikin \& Ani, 2014). It refers to the accessibility to places of interest/event. In literature, service convenience has been revised as customers' effort and time perceptions towards the use or purchase of services (e.g. Seiders, Voss, Godfrey \& Grewal, 2007; Berry, Seiders \& Grewal, 2002). Convenience was suggested by Adoyo et al. (2012) for examination in other service industries as among the relationship quality dimensions, the variable constituted $63 \%$ of the regression model used in their study. Future studies have been urged by Dai, Haried and Salam (2011) as well as Warsame (2015) to examine the influence of convenience on customer loyalty via the role of customer satisfaction in dynamic emerging economies.

In the hospitality industry, considering the many challenges that exist, loyalty initiatives have to be developed to bring about emotion between the customer-hotel relationships. Several studies including Andersen and Kumar (2006), Cheng and Rashid (2015) and Williams (2012) also evidenced that regardless of the works that attempted to explain the relationship marketing development, those that concentrated on emotion are still few and far between. Other studies like Chaparro-Pelaez, Hernandez-Garcia \& Uruena-Lopez (2015) and Williams (2014) suggested that future studies examine the way emotions influence customers' decisions to maintain or to break a relationship or how to establish the same.

The present study thus proposes an extended relationship marketing model where relationship quality is integrated with emotions to determine customer loyalty in 5-star hotels in Malaysia and Jordan, as developing countries as suggested in previous literature (Ali et al., 2016; Amiri \& Esmailpour, 2014; Kim et al., 2015; Nwokorie, 2016; Wilks \& Hemsworth, 2012). This is deemed to be a novel contribution to the hospitality loyalty literature.

\section{THEORETICAL FRAMEWORK}

The relationship marketing and social exchange viewed in this thesis develops with the help of a thorough literature review, and the integration of factors that were excluded in a single model by prior studies. The thesis attempts to offer a picture of an effective relationship marketing initiative by proposing that emotions, trust, brand image and convenience as an important variables in customer relationship development on loyalty context as showed in Figure 1.

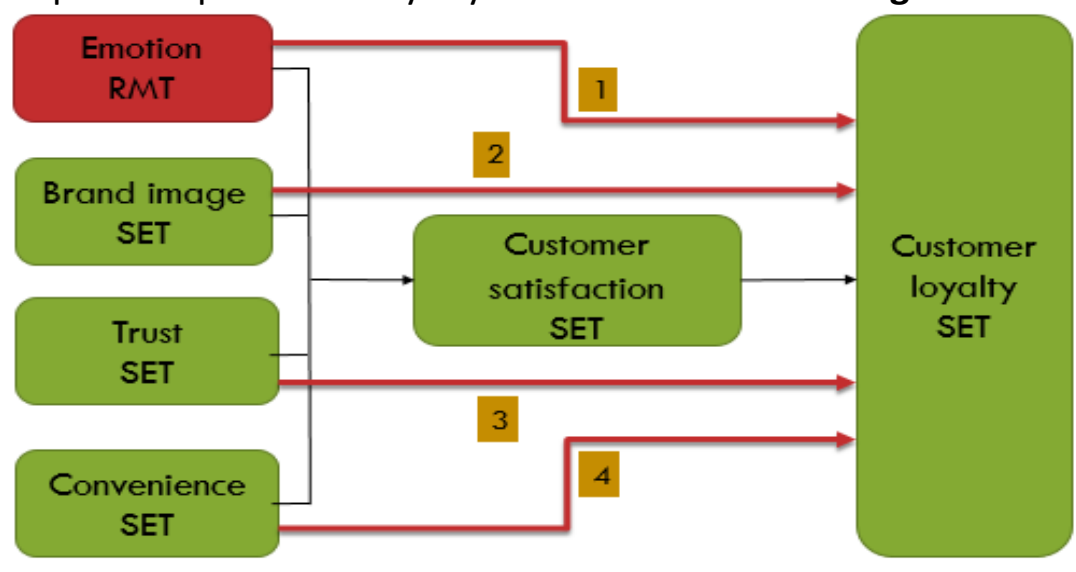

Theoretical gap 
INTERNATIONAL JOURNAL OF ACADEMIC RESEARCH IN BUSINESS AND SOCIAL SCIENCES

Vol. 8, No. 12, Dec, 2018, E-ISSN: 2222-6990 @ 2018 HRMARS

1- Recommendation by (Ali et al., 2016; Amiri \& Esmailpour, 2014; Kim et al., 2015; Nwokorie, 2016; Wilks \& Hemsworth, 2012).

2- Recommendation by (Abashah, 2015; Pelegrín-Borondo, Arias-Oliva, \& Olarte-Pascual, 2016; Tasci, 2016; Ullah, Raza, \& Chander, 2016).

3- Recommendation by (Ali et al., 2016; Amiri \& Esmailpour, 2014; Liu, Deng, Hu, \& Chen, 2015; Razak, Palilati, Hajar, \& Madjid, 2016; Suhartanto, 2011).

4- Recommendation by (Dai, Haried, \& Salam, 2011; Warsame, 2015).

\section{RESEARCH METHODOLOGY}

This research used a descriptive measurement method and a survey measurement. This descriptive methodology used in the research intentionally used to describe the characteristics of hotel industry and customers as well as to determine the characteristics answer who, when, where and what kind of problems. In addition, this research is designed to apply a survey method to build questionnaires to get the responses and more understanding about the customer attitudes and loyalty in the hotel industry in Malaysia and Jordan. According to (Zikmund et al., 1994), questionnaire is a measurement technique to collect data from a sample of the research community. Therefore, the data will be collected using two links on online of special five-star hotels in Jordan and one special five-star hotels in Malaysia. The total population in Malaysia was 752,260 and Jordan 9,537 (The Ministry of Tourism Malaysia and Jordan 2015). Accordingly, the first group which is Malaysia 5-star hotel guests has 384 sample, while the second group which is Jordan 5-start hotel guests has 370 sample (Sekaran, 2010), allowing an error rate that is less than $5 \%$ of the $95 \%$ level of reliability. Due to the impossible feat of including the entire units of the guest population, a convenience sampling was employed.

Table 1 below shows the list of these hotels and the guests that responded to the questionnaire during the data collection. Data for this study was collected between September and October 2016. Research assistants were employed to assist in distributing the questionnaire in Malaysia and Jordan.

Table 1: Data collected in Malaysia and Jordan

\begin{tabular}{|c|c|c|}
\hline \multirow{2}{*}{ Country } & Hotel & Data collected \\
\hline \multirow{3}{*}{ Malaysia } & Sheraton & $\mathbf{1 3 3}$ \\
\cline { 2 - 3 } & Le Meridien & 167 \\
\cline { 2 - 3 } & Marriott & 114 \\
\hline \multirow{3}{*}{ Jordan } & Sheraton & 158 \\
\cline { 2 - 3 } & Le Meridien & 99 \\
\cline { 2 - 3 } & Marriott & \multicolumn{2}{|c|}{} \\
\cline { 2 - 3 } & &
\end{tabular}

HYPOTHESIS TESTING RESULT OF DIRECT RELATIONSHIP OF VARIABLES

The hypotheses were tested in the desired model through three measures, the significance of Correlation Coefficients $(R)$, the Coefficient of Determination $\left(R^{2}\right)$, and lastly, the Multiple Regression (Beta).

$\mathrm{H}_{1}$ : Emotion, brand image, trust, and convenience are positively correlated with customer loyalty in Malaysia and Jordan. 
INTERNATIONAL JOURNAL OF ACADEMIC RESEARCH IN BUSINESS AND SOCIAL SCIENCES Vol. 8, No. 12, Dec, 2018, E-ISSN: 2222-6990 @ 2018 HRMARS

Table 2: The results of the application of the regression Emotion, brand image, trust, and convenience direct positively correlates with the customer loyalty

\begin{tabular}{|c|c|c|c|c|c|c|c|c|}
\hline & Variables & $\mathbf{B}$ & $\mathbf{T}$ & Sig. & $\mathbf{R}$ & $\mathbf{R}^{2}$ & $\mathbf{F}$ & Sig. \\
\hline \multirow{4}{*}{ Malaysia } & Emotion & 0.04 & 1.19 & 0.24 & \multirow{4}{*}{0.77} & \multirow{4}{*}{0.59} & \multirow{4}{*}{140.73} & \multirow{4}{*}{0.00} \\
\hline & Brand image & 0.47 & 10.04 & 0.00 & & & & \\
\hline & trust & $0.01-$ & $0.22-$ & 0.83 & & & & \\
\hline & convenience & 0.39 & 6.23 & 0.00 & & & & \\
\hline \multirow{4}{*}{ Jordan } & Emotion & 0.19 & 3.72 & 0.00 & \multirow[t]{4}{*}{0.41} & \multirow[t]{4}{*}{0.16} & \multirow[t]{4}{*}{18.59} & \multirow[t]{4}{*}{0.00} \\
\hline & Brand image & 0.17 & 3.34 & 0.00 & & & & \\
\hline & trust & $0.01-$ & $0.20-$ & 0.84 & & & & \\
\hline & venie & 0.21 & 341 & 000 & & & & \\
\hline
\end{tabular}

Based on the results indicated in the table (Table 2), in the Malaysian case, there is a statistical direct significant relationship between emotion, brand image, trust and convenience and customer loyalty at the significance level of $(p=0.05)$. The results indicate the correlation coefficient $(R)$ to be 0.77 , the $\left(R^{2}\right)$ to be 0.59 , and the value test $(F)$ to be 140.53 . Thus, the hypothesis is accepted. In the case of Jordan, a statistical significant direct and positive relationship was found between emotion, brand image, trust and convenience, and customer loyalty at the significance level of $(p=0.05)$. The results indicate that the value of correlation coefficient $R=0.41, R^{2}=0.16$, and the test value $F=18.59$ at $(0.00)$, with a statistical significance level of $(p=0.05)$ and thus, the hypothesis is accepted.

The second hypothesis proposes that;

$\mathrm{H}_{2}$ : Emotion, brand image, trust, and convenience are positively correlated with customer satisfaction in Malaysia and Jordan.

Table 3: The results of the application of the regression emotion, brand image, trust, and convenience direct positively correlates with the customer satisfaction

\begin{tabular}{|c|c|c|c|c|c|c|c|c|}
\hline & Variables & B & $\mathbf{T}$ & Sig. & $\mathbf{R}$ & $\mathbf{R}^{2}$ & $\mathbf{F}$ & Sig. \\
\hline \multirow{4}{*}{ Malaysia } & Emotion & 0.09 & 2.43 & 0.02 & \multirow{4}{*}{0.78} & \multirow{4}{*}{0.61} & \multirow{4}{*}{148.66} & \multirow{4}{*}{0.00} \\
\hline & Brand image & 0.36 & 7.85 & 0.00 & & & & \\
\hline & trust & 0.24 & 4.17 & 0.00 & & & & \\
\hline & convenience & 0.30 & 4.85 & 0.00 & & & & \\
\hline \multirow{4}{*}{ Jordan } & Emotion & 0.33 & 7.86 & 0.00 & \multirow{4}{*}{0.66} & \multirow{4}{*}{0.43} & \multirow{4}{*}{69.31} & \multirow{4}{*}{0.00} \\
\hline & Brand image & 0.40 & 9.27 & 0.00 & & & & \\
\hline & trust & 0.00 & 0.02 & 0.98 & & & & \\
\hline & convenience & 0.15 & 2.90 & 0.00 & & & & \\
\hline
\end{tabular}

On the basis of the results contained in Table 3, in the case of Malaysia, there is a statistical significant direct relationship between emotion, brand image, trust and convenience that is positive in nature with customer satisfaction at the level of significance $(p=0.05)$. The results indicated that $R$ is 0.78 , R-square is 0.61 , and the test value $F$ is 148.22 and thus, the second hypothesis is accepted. On the other hand, in Jordan, a statistical significance direct and positive relationship exists between emotion, brand image, trust and convenience, and customer satisfaction at the significance level of $(p=0.05)$. The results showed that $R$ is $0.66, R$-square is 0.43 , and the test value $F$ is 69.31 . 
INTERNATIONAL JOURNAL OF ACADEMIC RESEARCH IN BUSINESS AND SOCIAL SCIENCES Vol. 8, No. 12, Dec, 2018, E-ISSN: 2222-6990 C 2018 HRMARS

The third hypothesis proposes that;

$\mathrm{H}_{3}$ : Customer satisfaction is positively correlated with customer loyalty in Malaysia and Jordan.

Table 4: The results of the application of the regression customer satisfaction direct positively correlates with the customer loyalty

\begin{tabular}{|c|c|c|c|c|c|c|c|}
\hline & B & T & Sig. & R & R2 & F & Sig. \\
\hline Malaysia & 0.69 & 18.34 & 0.00 & 0.69 & 0.47 & 336.52 & 0.00 \\
\hline Jordan & 0.34 & 6.91 & 0.00 & 0.34 & 0.12 & 47.80 & 0.00 \\
\hline
\end{tabular}

The results presented in the above table (Table 4) concerning the proposed relationship between customer satisfaction and customer loyalty in the case of Malaysia supported the relationship at the level of significance $(p=0.05)$. Specifically, the values indicated that $R$ is $0.69, R$ square is 0.47 , and the $F$ test value is 336.52 . The values indicate support for the third hypothesis.

With regards to the Jordanian case, customer satisfaction was found to be positively and directly correlated with customer loyalty at the significance level $(p=0.05)$, where the following values were obtained; $R=0.34$, $R$-square $=0.12$, and $F$ test value $=47.80$. These values indicate support for the third hypothesis.

\section{TESTING THE MEDIATING EFFECT}

The developed research model contains four potential mediating effects between the exogenous variables and the dependent variables. They are proposed in the following hypothesis;

$\mathrm{H}_{4}$ : Customer satisfaction mediates the relationship between emotion, brand image, trust, convenience and customer loyalty in Malaysia and Jordan.

VAF value is less than $20 \%$, it can be conclude no mediation relationship. Value ranging "between" $20 \%$ to $80 \%$, can be characterized as partial mediation, and above $80 \%$, it can be assumed a full mediation (Hair Jr, Hult, Ringle, \& Sarstedt, 2016). Table (5) shows VAF in all variables in models:

Table 5: VAF mediator calculator

\begin{tabular}{|c|c|c|c|c|c|c|}
\hline & Variables & $\begin{array}{c}\text { Std. } \\
\text { Beta } \\
\text { Path a }\end{array}$ & $\begin{array}{c}\text { Std. } \\
\text { Beta } \\
\text { Path b }\end{array}$ & $\begin{array}{c}\text { Indirect } \\
\text { effect }\end{array}$ & VAF & Result \\
\hline Malaysia & Emotion & 0.09 & 0.69 & 0.064 & 0.49 & Partial Mediation \\
\cline { 2 - 7 } & Brand image & 0.36 & 0.69 & 0.372 & 0.40 & Partial Mediation \\
\cline { 2 - 7 } & Trust & 0.24 & 0.69 & $0.075-$ & 0.69 & Partial Mediation \\
\cline { 2 - 7 } & Convenience & 0.30 & 0.69 & 0.311 & 0.40 & Partial Mediation \\
\hline \multirow{3}{*}{ Jordan } & Emotion & 0.33 & 0.34 & 0.145 & 0.44 & Partial Mediation \\
\cline { 2 - 7 } & Brand image & 0.40 & 0.34 & 0.117 & 0.54 & Partial Mediation \\
\cline { 2 - 7 } & Trust & 0.00 & 0.34 & $0.012-$ & 0.00 & No Mediation \\
\cline { 2 - 7 } & Convenience & 0.15 & 0.34 & 0.22 & 0.22 & Partial Mediation \\
\hline
\end{tabular}

On the other hand, in Jordan, customer satisfaction was found to have a partial mediation effect towards the relationship between emotion, brand image, and convenience with customer loyalty. However, customer satisfaction was found to have no mediation effect towards the relationship between trust and customer loyalty. These findings contribute towards theoretical and 
practical knowledge by providing evidence about determinants of customer loyalty towards selecting five star hotels in Malaysia and Jordan.

The overall results supported the mediating effects of customer satisfaction between emotion, brand image, trust, convenience and customer loyalty. Based on the results contained in the above tables, in the Malaysian case, there is a statistical significant mediating effect of customer satisfaction on the relationship between emotion, brand image, trust, convenience and customer loyalty at the level of significance $(p=0.05)$. More specifically, the following values were obtained; $R=0.79$, $R$-square $=0.62$, and the $F$ test value is 125.279 . All the values indicate support for the proposed mediating hypothesis. In Jordan, similar to the Malaysian case, the results showed a statistical significant mediating effect of customer satisfaction on the relationship between emotion, brand image, trust, convenience and customer loyalty at the significance level $(p=0.05)$. Specifically, the following values were found; $R=0.42$, $R$-square $=0.18$, and the $F$ test value is 16.00 . Hence, the mediating effect is also supported in the Jordanian case. As can be seen from the interpretation above the $\mathrm{R}^{2}$ change is not a criteria or important factor in assessing mediation while in moderation the $\mathrm{R}^{2}$ change is an important criteria. In mediation the concern is the change in Beta value before and after the inclusion of the mediator variable (Baron \& Kenny, 1986; MacKinnon, 2011).

\section{RECOMMENDATIONS FOR FURTHER RESEARCH}

On the basis of the above limitations, future empirical research is called for to extend the study. The present study framework may be added to and extended to strengthen the findings and overcome the limitations. The research variables may be used in different sectors like the hospitals, restaurants and airports to determine their influence on customer satisfaction and loyalty. Moreover, the findings may differ when considered in other cultural groups. This indicates a need for future studies to conduct cross-cultural research to determine whether or not premium customers have the same behavior all over the globe, or whether Malaysian and Jordanian customers are unique due to their culture. In Sheth and Parvatiyar (1995) and Arnold and Bianchi (2001), the authors stressed on culture as a significant issue in consumer-business relationships. This is a significant issue, particularly for global service providers that focus on diverse customer range. Furthermore, despite the appropriate variance explained for both customer satisfaction and loyalty, other determinant variables like customer commitment as evidenced in prior studies (e.g., Chang, 2013; Martinez \& del Bosque, 2013; Razak, Palilati, Hajar \& Madjid, 2016), price (Shamsudin, 2012; Yan 2015), perceived value and reputation, among others may be included in the model to furnish a more extensive explanation of the variables. Lastly, it is also recommended that future studies include the direct and indirect effects between the variables to examine the moderating effects between them. For example, future studies could focus on the moderating effect of trust between emotion and customer loyalty, and the mediating effect of convenience between customer satisfaction and customer loyalty. This would furnish a deeper understanding of the variables relationships. 
INTERNATIONAL JOURNAL OF ACADEMIC RESEARCH IN BUSINESS AND SOCIAL SCIENCES

Vol. 8, No. 12, Dec, 2018, E-ISSN: 2222-6990 @ 2018 HRMARS

\section{REFERENCES}

Abashah, A. (2015). Service quality in early child care center, Does parents stisfied? (Master of science management, University Utara Malaysia.

Abdullah, A. A., \& Hamdan, M. H. (2012). Internal success factor of hotel occupancy rate. International Journal of Business and Social Science.

Adoyo, B., Ondoro, C. O., Ojera, P. B., Abong'o, B., Aila, F. O., \& Jeremiah, S. N. (2012). The Relationship between Customer Service Quality and Customer Loyalty among Retail Pharmacies in Western Kenya. Business and Management Review.

Ali, Kim, W. G., Li, J., \& Jeon, H.-M. (2016). Make it delightful: Customers' experience, satisfaction and loyalty in Malaysian theme parks. Journal of Destination Marketing \& Management.

Alrai. (2015). Challenges Facing the Incoming Tourism Sector. www.alrai.com/article/740008.html.

Amiri, M., \& Esmailpour, H. (2014). DI Impact of Customer Relationship Management on Customer Loyalty Chain Hotel. Kuwait Chapter of the Arabian Journal of Business and Management Review.

Andersen, P. H., \& Kumar, R. (2006). Emotions, trust and relationship development in business relationships: A conceptual model for buyer-seller dyads. Industrial marketing management.

Arnold, K., \& Bianchi, C. (2001). Relationship marketing, gender, and culture: Implications for consumer behavior. NA-Advances in Consumer Research Volume 28.

Aslan, A. (2014). Tourism development and economic growth in the Mediterranean countries: Evidence from panel Granger causality tests. Current Issues in Tourism.

Baron, R., \& Kenny, D. (1986). The moderator-mediator variable distinction in social psychological research: Conceptual, strategic, and statistical considerations. Journal of personality and social psychology.

Berezina, K., Cobanoglu, C., Miller, B. L., \& Kwansa, F. A. (2012). The impact of information security breach on hotel guest perception of service quality, satisfaction, revisit intentions and wordof-mouth. International Journal of Contemporary Hospitality Management.

Berry, Seiders, \& Grewal, D. (2002). Understanding service convenience. Journal of marketing.

Cárdenas-García, P. J., Sánchez-Rivero, M., \& Pulido-Fernández, J. I. (2015). Does tourism growth influence economic development? Journal of travel research.

Chang. (2013). How reputation creates loyalty in the restaurant sector. International Journal of Contemporary Hospitality Management.

Chaparro-Peláez, J., Hernández-García, Á., \& Urueña-López, A. (2015). The role of emotions and trust in service recovery in business-to-consumer electronic commerce. Journal of theoretical and applied electronic commerce research.

Chen, Sch, Kazman, R., \& Matthes, F. (2016). Amazon in the Air: Innovating with Big Data at Lufthansa. Paper presented at the 2016 49th Hawaii International Conference on System Sciences (HICSS).

Cheng, B. L., \& Rashid, Z. A. (2015). Interrelationships of Service Quality, Customer Satisfaction, Corporate Image and Customer Loyalty of Malaysian Hotel Industry Cultural Tourism in a Digital Era (pp. 37-38): Springer. 
INTERNATIONAL JOURNAL OF ACADEMIC RESEARCH IN BUSINESS AND SOCIAL SCIENCES

Vol. 8, No. 12, Dec, 2018, E-ISSN: 2222-6990 @ 2018 HRMARS

Chu, Tang, L., \& Luo. (2016). Two Decades of Research on Luxury Hotels: A Review and Research Agenda. Journal of Quality Assurance in Hospitality \& Tourism.

Dai, H., Haried, P., \& Salam, A. (2011). Antecedents of online service quality, commitment and loyalty. Journal of computer information systems.

Dogdubay, M., \& Avcikurt, C. (2009). Customer Lloyalty in the Specialty Restaurants: An example from Istanbul. Article of Professors of Balikesir University, Tourism and Hotel Management School,(Turizm Isletmeciligi ve Otelcilik YO), Cagis Kampus/Balikesir/Turkey, murat dogdubav@vahoo.com and cevdet avcikurt@vahoo.com.

Elbakoush, A. Y. (2015). The Influence of Service Quality, Corporate Image, Trust and Satisfaction on Customer Loyalty: Evidence from Banking Industry in Libya. (master), Universiti Utara Malaysia, malaysia.

Godolia, M., \& Spaho, A. (2014). Customer Satisfaction Measurement Practices In Hotels: Some Evidence from Albania.

Hair, J., Hult, T., Ringle, C., \& Sarstedt, M. (2016). A primer on partial least squares structural equation modeling (PLS-SEM): Sage Publications.

Hoq, M. Z., Sultana, N., \& Amin, M. (2010). The effect of trust, customer satisfaction and image on customers' loyalty in islamic banking sector. South asian journal of management.

Joppe, M., \& Li, X. P. (2014). Productivity Measurement in Tourism The Need for Better Tools. Journal of travel research.

Karjaluoto, H., Jayawardhena, C., Pihlström, M., \& Leppäniemi, M. (2015). Effects of Service Quality, Trust, and Perceived Value on Customer Loyalty: The Case of Mobile Subscribers. Paper presented at the Proceedings of the 2009 Academy of Marketing Science (AMS) Annual Conference.

Kawachart, P. (2013). Customer Satisfaction with Luxury Hotel in Bangkok: The Influence of Housekeeping Services Quality: European Real Estate Society (ERES).

Khanna, A., Papadavid, P., Tyson, J., \& te Velde, D. W. (2016). The Role of Services in Economic Transformation-With an Application to Kenya.

Kim, Vogt, \& Knutson, B. (2015). Relationships among customer satisfaction, delight, and loyalty in the hospitality industry. Journal of Hospitality \& Tourism Research.

Li, Ye, Q., \& Law, R. (2013). Determinants of customer satisfaction in the hotel industry: an application of online review analysis. Asia Pacific Journal of Tourism Research.

Liu, Deng, S., Hu, F., \& Chen, X. (2015). The impacts of unique service resources and habit on e-service loyalty in a highly competitive market. Journal of Systems and Information Technology.

MacKinnon. (2011). Integrating mediators and moderators in research design. Research on Social Work Practice.

Magnini, V., Crotts, J., \& Zehrer, A. (2011). Understanding customer delight an application of travel blog analysis. Journal of travel research.

Martínez, P., \& del Bosque, I. R. (2013). CSR and customer loyalty: The roles of trust, customer identification with the company and satisfaction. International Journal of Hospitality Management.

Mazghouni, N., \& Goaied, M. (2015). The Impact of Tourism on Economic Growth: The Case of MENA Region (1995-2013). Available at SSRN 2618598. 
INTERNATIONAL JOURNAL OF ACADEMIC RESEARCH IN BUSINESS AND SOCIAL SCIENCES

Vol. 8, No. 12, Dec, 2018, E-ISSN: 2222-6990 @ 2018 HRMARS

Morgan, R., \& Hunt, S. (1994). The commitment-trust theory of relationship marketing. The Journal of Marketing, 20-38.

Noorashikin, H., \& Ani, C. (2014). Website service quality, perceived value, trust, convenience and customer loyalty of online shopping. Universiti Utara Malaysia.

Nwokorie, E. C. (2016). Service recovery strategies and customer loyalty in selected hotels in Lagos State, Nigeria. Net Journal of Business Management, 4(1), 1-8.

Page, S. (2014). Tourism management: Routledge.

Pelegrín-Borondo, J., Arias-Oliva, M., \& Olarte-Pascual, C. (2016). Emotions, price and quality expectations in hotel services. Journal of Vacation Marketing.

Razak, A., Palilati, A., Hajar, I., \& Madjid, R. (2016). Customer Income Role as Moderation Variable of Satisfaction Effect on Customer Loyalty in Bank Negara Indonesia (Persero), Tbk. In Southeast Sulawesi.

Reicheld. (1996). The loyal effect: Boston, MA: Harvard Business School Press.

Sekaran, \& Bougie. (2010). Research methods for Business: A Skill Building Approach, A John Wiley \& Sons, Ltd: Singapore.

Seiders, K., Voss, G., Godfrey, A., \& Grewal, D. (2007). SERVCON: development and validation of a multidimensional service convenience scale. Journal of the academy of marketing science.

Shammout, A. B. (2007). Evaluating an extended relationship marketing model for Arab guests of fivestar hotels. Victoria University.

Shamsudin, M. F. B. (2012). Determinants Of Customer Loyalty Towards Prepaid Mobile Cellular Services In Malaysia. (Doctor Of Business Administration), Universiti Utara Malaysia

Sheth, J., \& Parvatlyar, A. (1995). Relationship marketing in consumer markets: antecedents and consequences. Journal of the academy of marketing science.

Shoemaker, S., \& Lewis, R. (1999). Customer loyalty: the future of hospitality marketing. International Journal of Hospitality Management.

Suhartanto, D. (2011). An examination of brand loyalty in the Indonesian hotel industry. Lincoln University.

Tasci, A. (2016). A quest for destination loyalty by profiling loyal travelers. Journal of Destination Marketing \& Management.

Ullah, A., Raza, M., \& Chander, S. (2016). Effect of Perceived Quality of Service on Customer Loyalty: A Case of Pearl Continental Hotel Services.

Warsame, A. E. (2015). Measuring factors affecting customer loyalty on Islamic banking deposit in Malaysia. Universiti Utara Malaysia.

Wilks, D., \& Hemsworth, K. (2012). Soft skills as key competencies in hospitality higher education: matching demand and supply. Tourism \& Management Studies.

Williams. (2012). Core qualities of successful marketing relationships. Journal of Management and Marketing Research, 10, 1.

Williams. (2014). Emotions and consumer behavior. Journal of consumer research, 40(5).

Wu, \& Liang, R.-D. (2009). Effect of experiential value on customer satisfaction with service encounters in luxury-hotel restaurants. International Journal of Hospitality Management.

Yan, Z. (2015). Factors Influence Customer Loyalty In Hotel Industry. (Master Of Science (Management), Universiti Utara Malaysia. 
INTERNATIONAL JOURNAL OF ACADEMIC RESEARCH IN BUSINESS AND SOCIAL SCIENCES

Vol. 8, No. 12, Dec, 2018, E-ISSN: 2222-6990 @ 2018 HRMARS

Yao, Z. (2013). Visual customer segmentation and behavior analysis: a SOM-based approach.

Zikmund, Vaněk, Havránková, Březina, Člermák, \& Vásša. (1994). Search for new molecular organic 